West European Politics

\title{
After the Spitzenkandidaten: fundamental change in the EU's political system?
}

\section{Thomas Christiansen}

To cite this article: Thomas Christiansen (2016): After the Spitzenkandidaten: fundamental change in the EU's political system?, West European Politics, DOI: 10.1080/01402382.2016.1184414

To link to this article: http://dx.doi.org/10.1080/01402382.2016.1184414

$$
\text { 曲 Published online: 13 Jun } 2016 .
$$

Submit your article to this journal ¿

Q View related articles $\square$

View Crossmark data ¿ 


\title{
After the Spitzenkandidaten: fundamental change in the EU's political system?
}

\author{
Thomas Christiansen
}

\begin{abstract}
The appointment of the President of the European Commission in 2014 occurred in the context of a novel environment: in constitutional terms, the Lisbon Treaty had introduced a small but significant change, namely the requirement for the candidate proposed by the European Council to be elected by the European Parliament. Politically, the 2014 European elections took place against the background of the eurozone crisis which had polarised opinions about the direction of European integration across the member states. This article develops a framework to assess the impact of this changed environment along two crucial dimensions of EU politics - interinstitutional relations and party politics. Based on this analysis, the article argues that while there has been gradual change in certain respects, the impact of the Spitzenkandidaten system did not lead to a transformation of the EU's political system. Indeed, rather than creating new opportunities for party political competition, the cooperation between centreright and centre-left in the election of the Commission President and subsequent decision-making further strengthened the long-standing 'grand coalition' in the European Parliament.
\end{abstract}

KEYWORDS European Union; European Commission; European Parliament; EP elections; constitutional change; eurozone crisis

The 2014 election to the European Parliament was branded by the Parliament's own PR department as an event that would be 'different this time' (European Parliament 2014). One reason why these elections could be considered 'different' was the expectation that due to the popular upheaval about the eurozone crisis they would result in a higher turnout, reversing the decades-long trend of declining turnout.

However, the 'official' reason why the 2014 election was expected to be different was the fact that with the coming into force of the Lisbon Treaty there had been a change to the appointment procedure of the President of the European Commission. Specifically, Art. 17, paragraph 7, stipulated that the European Council needed to 'take into account the elections to the European Parliament' 
in proposing a candidate for the Commission Presidency, and that the successful candidate would need to be 'elected' by the majority of MEPs.

Even though these were, on the face of it, only minor changes to the existing procedure - the Parliament's approval had already been required for the European Council's preferred candidate - they had a significant impact on the nature of campaigning for the elections: the treaty change opened the door for the European party families to put forward leading candidates for the position of Commission President, giving the European electorate for the first time the opportunity to determine not only the composition of the European legislature, but also the leadership of the EU's executive. These dynamics did not occur in a vacuum but coincided, and interacted, with other developments, in particular the crisis in the eurozone, the tensions that it created among and within member states, and the political consequences this has had domestically.

Against this background, the 2014 EP election marked a unique opportunity for the EU's electorate to vote on a genuinely pan-European issue directly affecting the majority of the citizens. Together with the enhanced role of the EP in the election of the Commission President, the 2014 election could therefore be expected to usher in a new era of European Union politics in which leadership changes result from popular choice rather than bargaining behind closed doors. In other words, there was an expectation that an election being held under such circumstances could be 'really different this time', indeed that it had the potential to become a transformative event in EU politics.

Analysing developments before, during and after the appointment of JeanClaude Juncker as Commission President, this article addresses the question as to whether such transformative change has actually occurred. More specifically, it goes beyond the analysis of the electoral campaign and the election result, and asks whether the confluence of treaty change and eurozone crisis has helped to transform EU politics in a lasting way. EU politics is conceptualised along two dimensions - interinstitutional relations and party politics - and an analytical frame identifies a number of parameters in order to assess the impact of the changing circumstances on the EU's political system.

\section{Treaty reform, eurozone crisis and the 2014 European elections}

A key factor explaining potential change in the EU's politics had been the revision of the treaty agreed at Lisbon in 2007, coming into force on 1 December 2009. In particular, the new wording of Art. 17, introducing the idea of an 'elected' Commission President, provided a powerful symbolic change to the previous practice of the holder of this post being 'appointed' by the heads of state and government and merely 'approved' by Parliament. Furthermore, in the context of latent interinstitutional battles between the EP and the European Council, it also constituted a new opportunity structure for the Parliament to enhance its powers. 
However, it is worth pointing out that the Lisbon changes to Art. 17 did not automatically lead to the Spitzenkandidaten system, but instead were contingent on a number of factors. First of all, the legal change was not that far-reaching, given that the Parliament already had de facto power to elect the Commission President, and a skilful, coherent and persistent strategy on behalf of the Parliament vis-à-vis the European Council arguably could have achieved the same outcome even without this change in the wording of the article.

In this context it should also be noted that the experience of 2014 was not only based on the new treaty provisions, but also on some long-standing commitments from supporters of a more parliamentary, if not federal, Europe (Westlake 2016). These preceded the treaty change in Lisbon, influencing as they did the debates leading up to and including the Convention on the Future of Europe. One such influence on the drafting of the treaty came from the European People's Party (EPP) at its Congress in Estoril in October 2002, calling for Parliament to 'give or withhold its approval by majority vote' (European People's Party 2002: Art. 47). There is no space in this paper for a complete process-tracing of the relevant passages in the treaty, but it will be evident from even this brief look that the new system arising in 2014 was not the outcome of a sudden and abrupt change, but rather the result of a gradual process of adaptation going back through several instances of treaty revision - one that arguably began in the 1996 IGC when the synchronisation of the terms of office of the EP and of the Commission was introduced (Dinan 1997: 199). The changes arising from the Lisbon Treaty, however significant, need to be seen in the context of a long-term process of continuous treaty reform (Christiansen and Reh 2009) - a process that gradually brought the Union to the point at which it became possible for minor changes to the appointment procedure to have a major impact on the functioning of the wider political system.

Historically, the EP has been an effective player in identifying opportunities for enhancing its position in the course of this treaty reform process. The EP is widely seen as the 'winner' in recent rounds of treaty reform (Beach 2007; Craig 2008), and the additional powers the EP received through the Lisbon Treaty have been widely discussed elsewhere. However, following the logic of treaty change as a continuous process, it becomes important to also consider developments in between rounds of formal treaty revision. Farrell and Heritier, in developing their concept of interstitial change, have advanced our understanding of the way in which 'incomplete contracts' contained in the treaties have allowed the EP to influence institutional change in its own interest (Farrell and Heritier 2007).

This is relevant in the present context, given the ambiguity of the phrase 'taking into account the outcome of the elections' in Art. 17, and the manner in which this was interpreted by parliamentary actors to the EP's advantage before and after the 2014 election. On this occasion, exploiting the openness of the treaty extended beyond the political realm, involving also the efforts of 
the EP's secretariat in launching the concerted campaign mentioned above, all on the basis of the claim that in 2014, 'for the first time, the composition of the new European Parliament will determine who will lead the next European Commission' (European Parliament 2014) - a claim that, while it turned out to be an accurate prediction of future developments, was not necessarily in line with the formal-legal position at the time of writing.

Beyond the parliament as a whole playing an institutional role, a key part of the process was the way in which the various party groups took up and utilised the opportunity offered to them on the occasion of the 2014 elections. Here the European People's Party (EPP), in recent years the largest group, played a pivotal but also contradictory role. The early initiatives of the EPP, dating back to the time before the Constitutional Convention, were already mentioned above. The EPP, on the back of a traditionally strongly parliamentary, if not pro-federalist, attitude towards the reform of the Union's institutions, had initially been in the vanguard of pushing for the election of the Commission President by the EP, and arguably had been among the strongest proponents of the Spitzenkandidaten system when this was initially discussed in the abstract (Westlake 2016). However, in the run-up to the 2014 election, faced with a European Council in which the EPP held the overwhelming majority, and with the party-political outcome of the elections far from certain, the EPP was rather reticent in its engagement with the system and late with the selection of a candidate for Commission President. In the end, the EPP was the last of the five parties fielding candidates to enter the race.

The background to this prevarication from the EPP was the initiative having been 'stolen' by the other political groups, most obviously by Martin Schulz who from his position as EP President launched an early and successful bid to become the candidate for the Party of European Socialists (PES). Against the background of a strong EPP majority in the European Council and after two terms of the 'EPP candidate' Commission President Juan-Manuel Barroso, chosen by the European Council, there was little to lose and everything to gain by the PES pushing for a greater parliamentary say in the choice. However, the outcome of such an initiative was far from certain; leading centre-left politicians holding office at the national level had little incentive to risk defeat in the uncharted waters of a new European electoral process. In this context, Martin Schulz had much to gain, and little to lose, by throwing his hat into the ring for the EU's top executive post.

The PES had already produced a timeline for its own Spitzenkandidaten in 2011, and on that basis Schulz then formally launched his campaign in the autumn of 2013, endorsed as a common candidate by most of the PES member parties. In November 2013 he was selected as 'candidate-designate' and from then on had a free and initially unopposed run as the Spitzenkandidat of the centre-left. He and his party clearly took this campaign seriously, something which then created dynamic effects for other party families and for the process 
as a whole. Schulz was eventually joined by rival candidates from the smaller party groups in the EP: Guy Verhofstadt, selected as candidate by the Alliance of Liberals and Democrats for Europe (ALDE) in February 2014, Ska Keller and José Bové who emerged victorious from a 'virtual primary' election conducted by the Greens in January 2014, and Alexis Tsipras, who had been nominated by the European left in December 2013.

Towards the end of 2013, the dynamics of this process began to become apparent: competitive pressures leading all of the main parties to seriously consider the implications of participating - or not participating - in this campaign with a leading candidate; the rising attention from media - initially EU-specific, but gradually also mainstream - to the internal decision-making processes and the inter-party rivalry; the emerging public expectation, based on the EP's own PR campaign and generally repeated in the reporting about the events, that this process would indeed determine the Commission Presidency. These dynamics ultimately forced the hand of the EPP in also putting forward its own candidate, with Jean-Claude Juncker winning the vote against then Commissioner Barnier at the EPP Congress in Dublin in March 2014.

While Juncker had all the credentials to be a leading candidate for the Commission Presidency - indeed he is said to have been serious contender already in 2009 when he lost out during bargaining in the European Council - it was also fortuitous from the perspective of the EPP that he had become available for the European position following his party's defeat in recent national elections in Luxembourg. Having been a constant in the European Council and as Chair of the Eurogroup during 18 years as Prime Minister and 10 years as Finance Minister of Luxembourg, Juncker was out of executive office from December 2013, and hence easier to convince to enter a race for the election as Commission President at a time when it was not certain that the EPP would indeed win this race. At the EPP Congress in Dublin in March 2014, Juncker received the nomination of his party, winning a vote against former Commissioner Michel Barnier with 382 to 245 votes.

Campaigning for the 2014 EP election did not occur in a vacuum, but happened against the background of the greatest crisis the EU had to face up to this point. Since 2010, when the economic and financial crisis required a response from the members of the eurozone, there had been long-lasting and acrimonious debates about the best way to manage the danger of sovereign debt default in some member states, the need for bail-outs and the corresponding demands for structural reforms in the debtor countries. In the process, it also constituted the first time that EU policy-making invoked popular and elite responses from across the European Union, dominating the campaigns and debates by the candidates for the Commission Presidency.

The eurozone crisis brought to light severe fissures within the European polity, and the allegation that much of the crisis management had been handled in a technocratic and/or intergovernmentalist manner, without sufficient 
democratic legitimacy, became a point of debate in most eurozone member states. Growing support for political parties and movements in several member states that were critical of the handling of the crisis, both in the creditor states and the programme countries, provided ample evidence for this rising sceptical trend - creating an electoral landscape in which it has become increasingly difficult for incumbent governments or even mainstream parties to maintain their position in the polls. The success of Syriza in Greece, in particular, heralded electoral success for anti-austerity policies that were at loggerheads with the pre-existing consensus among governments, with further backlash from disenchanted voters in other member states.

Such contestation has politicised existing tensions, with the technocratic approach relying on the work of the 'troika' of the European Central Bank (ECB), International Monetary Fund (IMF) and European Commission officials becoming the subject of much political debate and criticism. Consequently, the Eurogroup of Finance Ministers, and indeed the European Council, became essential fora for crisis management. In the context of responding to the eurozone crisis, the EU accumulated additional competences, without recourse to formal treaty change that would improve the legitimation of the greater role played by the European institutions. Instead, key decisions have increasingly been made by non-majoritarian institutions, within intergovernmental fora or through new arrangements outside the treaty structure.

These dynamics created a new context for election campaigning: the very fact of having Spitzenkandidaten at the European level (in addition to the domestically leading candidates that many of the component parties nominated to head national lists) did insert a new transnational dimension in the process. As Schulz, Juncker and the other candidates were competing for a European elected office, as leading candidates of the transnational party families, they could not limit themselves to campaigning only in their own constituencies or home countries. Indeed, as neither Juncker nor Tsipras were standing for election as MEPs, they might otherwise not have been campaigning at all.

Instead, the candidates had to appeal to a broader, pan-European audience, an expectation that was reflected in the many visits that each of them made across the member states of the European Union (Hobolt 2014). While such transnational campaigning was inevitably selective and conditioned by the limited time and financial resources available to the candidates, it nevertheless marked a small, yet significant departure from past experience when European election campaigns were largely a compartmentalised affair taking place within the boundaries of the respective member states.

Beyond meeting local candidates and supporting the component parties of their respective party families, a major concern in such campaigning was the garnering of media attention and increasing the name recognition of the Spitzenkandidaten. While initial research has shown that such media attention has had a certain, albeit limited effect on the recognition of, and the votes for, 
the respective candidates, this also constituted a two-sided process: candidates were more prone to campaign in countries where they were already known, and where there could be an expectation that their appearance would have a positive effect on the electorate (Schmitt et al. 2015).

However, size - of member states' populations and hence their share of seats in the EP - also mattered, and consequently Germany attracted by far the largest number of campaign visits, ahead of France and Belgium. The fact that there were noticeably fewer visits by the candidates of the top three parties (Juncker, Schulz, Verhofstadt) to Spain and Italy also indicates that language matters - that there are fundamental limitations to the capacity of candidates, however polyglot they may be, in a multilingual space such as European election campaigning.

Another aspect worth mentioning is that in certain member states the Spitzenkandidaten were not welcome: all three of the main British parties declared their opposition to the emerging system and consequently did not invite them to join their respective national campaigns. Consequently, the UK was the only member state, apart from Hungary, that was not visited by any of the top three candidates. The fact that the leaders of these two states ended up voting against the appointment of Jean-Claude Juncker in the European Council is perhaps not entirely unrelated.

Yet more significant than campaign visits was arguably the arrival of US-style presidential debates involving all or some of the candidates. Starting with the 'First European Presidential Debate' held in Maastricht on 28 April 2014, four televised debates open to all the candidates were being organised. In addition, Juncker and Schulz sparred in a number of head-to-head debates aired by French, German and Austrian broadcasters. Even if these debates were clearly not the prime-time TV events familiar from US presidential races, they did nevertheless constitute an entirely new experience of European electioneering, raising interesting questions about the way in which a genuinely European democracy might work.

\section{Analysing the impact of the Spitzenkandidaten on the EU's political system}

There is no doubt that the arrival Spitzenkandidaten and the new style of election campaigning constituted a novel departure in the history of the EU. Yet the impact that this had on the outcome of the election was more limited, and disappointing in terms of the high expectations that advocates had of the new system. The downward trend of voter turnout was not reversed, and in comparison to national elections voting for the EP remained decidedly second-order (van der Brug et al. 2016). Even though there had been, as discussed, significant changes to the structural context in which the 2014 election was fought, its immediate outcome was more in line with the secular trends of previous elections. 
But what about the longer-term impact of this election on the EU's political system? Implicit in the above discussion, and indeed in the wider debate about the introduction of the Spitzenkandidaten, was the claim that there was considerable potential for a fundamental transformation of EU politics. In analysing the degree of political change that has actually taken place, this article follows a historical institutionalist approach, a choice that is warranted given that the question about the implications of the change in appointment procedure constitutes precisely the kind of puzzle that has attracted historical institutionalist research in the past:

Historical institutionalists address big, substantive questions that are inherently of interest to broad publics as well as to fellow scholars. To develop explanatory arguments about important outcomes or puzzles, historical institutionalists take time seriously, specifying sequences and tracing transformations and processes of varying scale and temporality. Historical institutionalists likewise analyze macro contexts and hypothesize about the combined effects of institutions and processes rather than examining just one institution or process at a time. Taken together, these three features - substantive agendas; temporal arguments; and attention to contexts and configurations - add up to a recognizable historical institutional approach. (Skocpol and Pierson 2002: 696)

Essential in such an approach is the need to consider the historical trajectory of political developments, and to identify the process that has established the institutional context in which current decisions are being made - something that is highly pertinent in the case of the Spitzenkandidaten as an instance of parliamentary influence in the EU's political system. In fact, ever since the first direct election to the EP in 1979, key aspects of the EU's political system - the nature of European elections, the internal politics of the EP and the position of the parliament in the EU's institutional structure - have followed a particular pattern: parliamentary business has been dominated by the two largest groups, the EPP and the Socialists and Democrats (S\&D), European elections have remained second-order elections, and the influence of the EP in the EU's political system has gradually expanded.

In this regard, the historical institutionalist perspective will help to identify whether developments after the 8th parliamentary elections have continued along this path, or whether the discourse about fundamentally different elections in 2014 has translated into significant change in political practice. In theoretical terms, the question then is whether the introduction of the Spitzenkandidaten, in conjunction with the impact of the eurozone crisis, constituted a critical juncture in that it rearranged the EU's institutional architecture and opened up an entirely new chapter of EU politics.

In order to answer that question, we need to identify the parameters of institutional change (or continuity) along the two dimensions on which political change may occur, namely the EU's interinstitutional relations and its party politics. The subsequent analysis will be grounded in an understanding of the way EU politics operates along these two dimensions, and proceeds by identifying 
those aspects of the system that are considered analytically relevant for the purposes of this article.

Interinstitutional relations can be studied by assessing change with respect to the following three aspects:

- relations between the European Parliament and the European Council;

- relations between the European Parliament and the European Commission;

- the balance between supranational and intergovernmental elements of the EU's institutional structure.

In addition, investigating the potential transformation of EU party politics involves the study of:

- the nature of coalition formation among groups in the European Parliament.

While recognising the complexity of EU politics, and the challenge of measuring change in such a complex system, these four criteria constitute a logical way of determining whether interinstitutional relations and party politics have been transformed as a result of the new arrangements. They can serve as a useful heuristic device in order to facilitate a systematic analysis of the degree of change that has occurred. In the following section, these criteria structure the empirical analysis of post-election developments and allow us to come to a first assessment of the impact of the Spitzenkandidaten on the EU's political system.

\section{Interinstitutional relations}

A review of the institutional impact should start with the relations between the European Council and the European Parliament. These two institutions with their very different sources of legitimacy were clearly at loggerheads over their respective claims concerning the pick of the Commission President. With the legal framework not providing a clear-cut answer, as discussed earlier, this question turned into a test of political will - a test that to a large extent depended on the internal cohesion within each institution, and one that the EP ultimately decided for itself.

The European Council as an institution, and the majority of its members, had from the beginning been reserved about, if not opposed to, the assumptions behind the Spitzenkandidaten process. As an institution at the summit of the Union's decision-making process that had hitherto been the natural forum for the selection of the Commission President, it stood to lose significant power if the EP managed to wrest control over the process from it. Defensive measures had already started early: discourse about the European Council having the right to propose its candidate - and not one 'imposed' on it by Parliament - grew stronger as election week came closer, and became dominant in the days afterwards. European Council President van Rompuy had also scheduled 
an early European Council meeting right after the election - strategically, as many observers assumed, so as to pre-empt any momentum gathering behind the winning Spitzenkandidat (Euractiv 2014). The expectation was that the EP would need weeks if not months to constitute itself and to achieve sustained support for the majority candidate, giving the Heads of State and Government time to come up with a common position behind an alternative candidate.

However, in the event, the European Council never managed to coalesce around a credible alternative. Instead, the EP managed to pre-empt even the swift gathering of Heads of State and Government, with the main parties throwing their weight behind Juncker and supporting his election, albeit under certain conditions. What followed were a couple of weeks of prevarication during which the European Council as a whole, and key members such as Chancellor Merkel, seemed undecided on how to respond to the EP's challenge. There was vocal opposition to Juncker from some quarters - David Cameron in particular launched a campaign against the candidature of Jean-Claude Juncker, culminating in a mini-summit of conservative leaders in Harpsund, Sweden, on 10 June. If the objective of David Cameron here was to convince Angela Merkel to oppose Juncker's election with the help of fellow sceptics Mark Rutte (NL) and Frederik Reinfeldt (S), then it backfired, as both Rutte and Reinfeldt ultimately also voted for Juncker.

Merkel was key in this process that eventually swayed the European Council to agree on the EP's candidate. She had been less than supportive of Juncker's candidature in the run-up to the election, emphasising for example that for her there was no automatic link between selecting a leading candidate and the appointment to executive office (Tagesschau 2014). After the election, her apparent dithering about whether or not to accept the parliamentary majority in favour of Juncker created something of a storm in the German media, with accusations of backsliding and broken electoral promises mounting quickly (see Frankfurter Rundschau 2014; NDR online 2014). In the end, under such domestic pressure, and lacking any obvious alternative, Merkel came around to support for Juncker, which then cleared the way for a majority in the European Council and his election by the EP.

This brief period after the election demonstrated that the EP, with a high degree of internal cohesion on this issue, was able to expose the divisions and uncertainties present in the European Council. The parliament's insistence that it would oppose any other candidate than its own choice made it prohibitively risky for anyone else to let their name go forward. This was a very public interinstitutional dispute, and one that the EP managed to sway decisively in its own favour.

However, the victory of the EP vis-à-vis the European Council occurred against the backdrop of a growing intergovernmentalisation of $\mathrm{EU}$ decision-making which negatively affected the role of the EP, despite its gains in successive rounds of treaty reform. This development, and the empowerment 
of the European Council in particular, is largely due to the impact of the eurozone crisis and the manner in which governments have responded to it. The argument that scholars have advanced regarding the 'integration paradox' in the post-Maastricht era juxtaposes the expansion of EU competences with the stagnation of the powers of the supranational institutions (Bickerton et al. 2014). And while a critique of this view has pointed out that the impact of the eurozone crisis has been rather mixed and also involved the strengthening of supranational actors such as the Commission and the ECB (Dehousse 2015; Schimmelfennig 2015), the EP has been marginalised in the process.

In other words, the EP has gained power vis-à-vis the European Council in the context of appointment of the Commission President - an event happening only every five years - but its influence remains limited in key areas of non-legislative decision-making such as the eurozone or the refugee crisis. This means that an argument about the transformation of EU politics depends to a large extent on the relationship between the EP and the European Commission, namely the question whether the EP, through its success in choosing the Commission President, has transformed its relationship with this part of the EU's executive.

In this regard, there has been a strong sense that this link has indeed been strengthened, with a Commission President emerging from the EP's electoral process, and the winning candidate therefore being the EP's Commission President. Developments after the election provide evidence both for and against this particular view. First among the objections is the argument that the Parliament does not 'own' the entire Commission, however strong its ties are with the President. Commissioners continue to be appointed by the member states (via the European Council), and the President is merely a primus inter pares within a college that continues to decide by simple majority.

The EP had for some time managed to impose itself on the appointment procedure of designated Commission members by subjecting these to hearings before the relevant committee prior to their appointment, and has on occasion succeeded in objecting to individual appointments or specific allocations of portfolios. This long-standing pattern continued also with the members of the Juncker Commission, and indeed the EP also flexed its muscles on this occasion when it successfully objected to Alenka Bratušek, the former Slovenian Prime Minister who was nominee for the post of Energy Commissioner. After a poor performance in her hearing the MEPs voted against her appointment, and Slovenia then nominated Violeta Bulc, who in due course was appointed as Transport Commissioner.

However, none of this constituted a major shift from previous practices. On the whole, the composition of the college was dominated by member state preferences, and the allocation of portfolios negotiated between Presidentdesignate Juncker and national governments. With regard to the latter, Juncker demonstrated a degree of independence in handing Vice-Presidential positions 
exclusively to candidates nominated by small and medium-sized member states (with the exception of Federiga Mogherini), while at the same time recognising national preferences in assigning key portfolios such as economic and financial affairs to Pierre Moscovici (France) and financial services (Jonathan Hill). In any case, any claims that the EP would 'own' the Commission due to the new election procedure ignores the intergovernmental dimension of the European Commission which is deeply entrenched and goes beyond the point of appointment. The tensions between intergovernmental and supranational dynamics is present not only between EU institutions, but also within them, and the strong links between Commissioners and member states is a case in point (Christiansen 1997). As Fabbrini has argued, this in itself constitutes a considerable obstacle to the kind of 'parliamentary government' that advocates of the Spitzenkandidaten process had expected (Fabbrini 2015b).

The real test of a transformation in the relations between Parliament and Commission then lies not in the appointment of the members of the college, but rather in their interaction during subsequent legislative and other decision-making processes. Did the EP's ownership of the appointment of the Commission President result in a closer alliance between the two institutions? Did the Commission in fact evolve into a European government able to rely on a stable majority in Parliament?

Developments over the first year after Juncker's appointment paint a mixed picture. For a start, a closer personal relationship appears to have developed between the presidents of the two institutions, Juncker and Schulz. Having been the protagonists of the Spitzenkandidaten experience, and owing their positions to the outcome of the subsequent interinstitutional bargaining, demonstrated a capacity for close cooperation on several occasions. Under Schulz's leadership, the EP did deliver parliamentary support to Juncker on key dossiers such as the European Investment Plan, the measures proposed by the Commission in response to the 2015 refugee crisis, or the negotiations about a Transatlantic Trade and Investment Partnership (Shackleton 2015).

Beyond this, the close cooperation between EP and Commission has been institutionalised in the form of the so-called G5: regular meetings between Juncker, Schulz, Commission First Vice-President Frans Timmermans, and the leaders of the EPP and S\&D groups in the EP, Manfred Weber and Gianni Pitella, respectively (Politico 2015). Forging a close alliance between the key players in the Commission and the EP, the introduction of the G5 also constituted an institutionalisation of the new coalition politics following the 2014 election, to be discussed further below. Yet beyond formalising a coalition of EPP and S\&D, it also facilitated strategic cooperation between the two institutions, advancing their common position vis-à-vis the Union's intergovernmental institutions.

This arrangement does not mean that the Commission would always be assured of a majority in Parliament - the search for majority support for Commission initiatives remains a challenge on a case-by-case basis. Most 
strikingly, the Commission, in the context of its Better Regulation initiative, drastically reduced the number of new legislative initiatives it intends to launch, and furthermore withdrew a host of legacy proposals that had already been introduced by the Barroso Commission. In doing so, the Commission limited the role of the EP: legislation had long been the essence of parliamentary power in the EU, and the absence of a regular flow of new proposals has been likened to a room without oxygen for the Parliament.

However, the reduction in legislative proposals is to some extent balanced by a more comprehensive and predictable political agenda of the European Commission. Juncker stood for election in the Parliament not only on the basis of his party's manifesto, but a more detailed set of priorities that he announced on 15 July 2014. This 'Juncker Plan' contained 10 priority objectives for the period 2014-2019, and even though these were fairly broad, it established greater predictability of the Commission's work. Crucially, it facilitated an improvement in the EP's capacity for holding the Commission to account: annual work programmes and legislative initiatives could now be assessed in relation to the priorities Juncker had committed the Commission to at the point of his election - something he recognised when stating in his speech that 'we feel bound by a contract with this House, drawn up to run for five years. The first port of call for the new Commission will be this House' (Juncker 2014).

Furthermore, while the paucity of legislative proposals has limited the EP's involvement in decision-making in 2015, it also provided space for other kinds of parliamentary activity. Chief among these has been the EP's function as a forum for public debate on key issues. The growing number of state leaders speaking in the Parliament is evidence of this trend. In 2015, this included the French President, the German Chancellor and the Greek Prime Minister all debating with MEPs their policies in the eurozone crisis. Both the Hungarian and the Polish Prime Minister confronted MEPs in the context of criticisms from the EU institutions about domestic reforms in their respective countries. In the context of this trend, Martin Schulz's 'invitation' to David Cameron, to come to the EP and debate with them the plans for a British referendum and the negotiation of a deal to prepare for that, turned into something of an obligation - a call that Cameron only answered late and partially when agreeing to meet with group leaders in February 2016.

In this manner, the EP has arguably created a European forum in which state leaders account for their domestic policies insofar as these have relevance for the European Union as a whole, and comes in addition to the EP's scrutiny of the European institutions, with the Presidents of the Commission, the European Council and the European Central Bank facing MEPs on a regular basis to report on their work. This interaction with state leaders has helped to raise the Parliament's profile and contributed to a wider European debate about controversial policies within specific member states, albeit at irregular intervals and without formal obligation. 
The politicisation of the European Commission, the closer relationship between Parliament and Commission and the emergence of the EP as an accountability forum for the member states can all be seen as evidence of the greater parliamentarisation of the European Union that has followed the introduction of the Spitzenkandidaten system. However, these trends come up against the structural limitations of the EU as a hybrid polity in which key areas of decision-making remain in the hands of national governments (Fabbrini 2015a).

\section{Party politics}

The 2014 election result, with its growing share of seats going to anti-European, Eurosceptic and populist parties, was remarkable, yet they did not fundamentally alter the situation within the European chamber which has traditionally relied on collaboration of pro-integrationist groups from centre-left and centre-right. Indeed, rather than an electoral 'earthquake' upsetting the traditional way of doing things, the immediate and somewhat counter-intuitive effect of the 2014 election result was to create an even stronger, more cohesive centre-ground in the parliament.

The initial bond here was the commitment from the parties participating in the Spitzenkandidaten process that one of their candidates, and only one of their candidates, would be considered a legitimate proposal from the European Council. It was a position that was quickly reaffirmed right after the election results came in, when Martin Schulz conceded defeat on behalf of the Socialists, and immediately demanded that Jean-Claude Juncker as the candidate of the EPP, holding most seats in the new parliament, should become Commission President - a position that was soon afterwards endorsed by the leaders of the majority of groups in the EP (Spiegel Online 2014a).

In effect, within 24 hours of the last polls closing, this marked the confirmation that the centre parties would work together, in defence of the broader parliamentary interest, vis-à-vis the European Council. And while that interinstitutional confrontation took some weeks to play out, the close cooperation between centre-right and centre-left in the election of the Commission President as well as the other appointments to senior posts demonstrated that the grand coalition was not only very much intact, but actually strengthened by this particular election outcome. On 24 June the representatives of EPP and S\&D came to an agreement in order to 'shape a stable and sustainable majority in the European Parliament', an agreement to which the ALDE group then adhered only two days later (European Voice 2014).

While in the past such EPP-S\&D agreements had been common, for example by facilitating the sharing of the post of EP President over the EP's five-year term, in the light of the Spitzenkandidaten this dimension of coalition politics had much wider significance, involving also the election of the Commission 
President and the party-political couleur of other senior appointments. The cornerstones of this 'deal' were the support of the Socialists for Jean-Claude Juncker as Commission President and the support of the EPP for Martin Schulz to continue as EP President (Spiegel Online 2014b). This meant that the traditional 'grand coalition' at the political centre of the EP not only continued to function effectively, but that it became somewhat institutionalised in the form of the above-mentioned G5 meetings. It also meant that the Martin Schulz, as serving EP President, could remain in post - indeed, there is even the possibility that Schulz might serve out the full term of five years - an unprecedented development - as a result of the EPP-S\&D power-sharing deal.

The recognition that there has been less, rather than more, left/right competition in the post-2014 EP is not only based on the formation of the grand coalition that was established in order to elect Jean-Claude Juncker and agree on the other key appointments in 2014. Cooperation among the centrist and prointegrationist parties was also required, more than before, due to the greater size of the anti-establishment parties in the post-2014 parliament. Once it had become virtually impossible to form a constructive majority in Parliament without either the centre-right or the centre-left, these parties are bound to greater cooperation.

This strengthening of the 'grand coalition' at the centre of the EP has occurred in stark contrast to the expectations expressed prior to the election, but also clashes with the predictions made by scholars only some 10 years earlier. Before the 2004 enlargement there was an anticipation that the arrival of the 10 new member states 'should further stabilize the party system in the EP ... by increasing the size of the two main party groups against the smaller groups, and by strengthening the bi-polar nature of competition in the EP' (Hix et al. 2003). In the wake of the 2014 election, the exact opposite appears to have happened: the size of the two main groups has shrunk, and that in turn has strengthened the bi-partisan rather than the bi-polar nature of the chamber. If anything, the pro-/anti-European cleavage in the Parliament has become more important, not least in the wake of the eurozone crisis and subsequent years of austerity policies (Höpner 2014).

\section{Conclusions}

The European election in 2014 was indeed different, but did this new kind of electioneering transform EU politics? Looking across the two key dimensions of EU politics identified, the Spitzenkandidaten system produced something of a supranational moment in the evolution of the EU's institutional architecture: the EP taking the reins from the European Council in the choice over the Commission President initially strengthened the EP, but above all empowered the Commission by enhancing its legitimacy and affording it greater independence from the member states. In particular, the President of the Commission, 
less encumbered than his predecessor by the need for support and approval from the majority of the member states, has been able to assume a leadership role unseen since the days of Jacques Delors.

In terms of the relations between the EP and European Council, this was indeed a moment rather than a wider transformation, with the effects of the eurozone crisis more than counteracting the impact of the new electoral procedure. There has, however, been closer and more systematic cooperation between the EP and Commission, with the election of the Commission President by the Parliament on the basis of a set of political priorities and the formal agreements between the EPP and S\&D groups. A 'governing coalition' of sorts has been established, and regular meetings between the leadership of both institutions helps to maintain this cooperative relationship. However, this does not guarantee certain support for Commission proposals in the way national governments can rely on their parliamentary majorities - the Commission's search for majority support for its proposals on a case-by-case basis continues, as does its close cooperation with member states and the European Council in a range of important non-legislative domains. In other words, there have been changes in the EU's interinstitutional relations, but these hardly amount to the kind of critical juncture that would throw the Union off its established path.

With respect to the dimension of party politics, the kind of changes that could be observed have also been limited. Indeed, neither pre-election campaigning nor post-election decision-making delivered greater party-political competition or a genuine choice between rival political programmes. Instead, with greater popular engagement and the development of a pan-European public sphere, the result has been a further strengthening of the pro-integrationist establishment in the face of rising populist opposition to further integration. In party-political terms, then, the introduction of the Spitzenkandidaten process has been characterised by a mismatch between, on the one hand, the promise of a clearer choice between rival candidates and a more competitive party system in the EP, and, on the other hand, the continuation of long-term trends in EU politics: the close cooperation between the pro-integrationist parties at the centre of the EP's political spectrum.

The overall conclusion of this analysis points to gradual adjustments in the EU's interinstitutional relations, combined with the continuation of prointegrationist coalition politics among the largest parties in the EP. It does not amount to a fundamental shift in the politics of the European Union, and in fact it is remarkable how the very different kind of election campaigning under the Spitzenkandidaten system has been followed by the reaffirmation of bipartisan party politics. Far from having constituted a critical juncture, the impact of the 2014 election has been to confirm the continuity of key aspects of the EU's political system. Path dependency rather than fundamental transformation has characterised the EU's interinstitutional relations and party politics, even 
though from mid-2015 the refugee crisis and the instability on the EU's borders raises new questions about the direction of future developments.

It has to be recognised that this is a very preliminary finding, based on less than two years of political activity since the European elections in May 2014. A more thorough assessment will only be possible in 2019, when the institutions, parties and winning candidate can be judged against their performance at the end of the current parliamentary term. In fact, the real litmus test may be whether the European elections in 2019 will see greater competition between rival candidates for the Commission Presidency - involving candidates not only from the mainstream parties, but also from critical and Eurosceptic camps. Such a development would create the prospect for more relevant debates about the future of Europe, and greater potential to realise the kind of political change that the Spitzenkandidaten system was supposed to deliver.

\section{Acknowledgements}

Initial ideas for the article were presented at the first EUI-EP Policy Dialogue in Brussels in December 2014, and a first draft was presented at a workshop at the Robert Schuman Centre for Advanced Studies at the EUI in Florence in September 2015. I am grateful for the insightful feedback received on both occasions, and also for the valuable comments provided by the journal's two anonymous referees. The article also benefitted greatly from the author's conversations with Michael Shackleton and Martin Westlake. Any remaining errors are solely my responsibility.

\section{Disclosure statement}

No potential conflict of interest was reported by the author.

\section{Notes on contributor}

Thomas Christiansen holds a Chair in European Institutional Politics in the Department of Political Science at Maastricht University, The Netherlands and is also part-time Professor at the European University Institute, Florence. He is Executive Editor (with Simon Duke) of the Journal of European Integration, co-editor (with Sophie Vanhoonacker) of the 'European Administration Governance' book series at Palgrave Macmillan and member of the board of the Research Committee on European Unification of IPSA. He has published widely on different aspects of European integration. [t.christiansen@maastrichtuniversity.nl]

\section{References}

Beach, Derek (2007). 'The European Parliament in the 2000 IGC and the Constitutional Treaty negotiations: from loser to winner', Journal of European Public Policy, 14:February, 1271-92. 
Bickerton, Christopher J., Dermot Hodson, and Uwe Puetter (2014). 'The New Intergovernmentalism: European Integration in the Post-Maastricht Era', Journal of Common Market Studies, 53:4, 703-22.

Van der Brug, Wouter, Katjana Gattermann, and Claes H. De Vreese (2016). 'Introduction: How Different Were the European Elections of 2014?', Politics and Governance, 4:1, 1-8.

Christiansen, Thomas (1997). 'Tensions of European Governance: Politicized Bureaucracy and Multiple Accountability in the European Commission', Journal of European Public Policy, 4:1, 73-90.

Christiansen, Thomas, and Christine Reh (2009). Constitutionalizing the European Union. Basingstoke: Palgrave Macmillan.

Craig, Paul (2008). 'The Role of the European Parliament under the Lisbon Treaty', in Stefan Griller and Jacques Ziller (eds.), The Lisbon Treaty. Vienna: Springer, 109-34.

Dehousse, R. (2015) 'The New Supranationalism', Paper prepared for presentation at the ECPR General Conference, Montreal.

Dinan, Desmond (1997). 'The Commission and the Reform Process', in Geoffrey Edwards and Alfred Pijpers (eds.), The Politics of European Treaty Reform. London: Pinter, $188-11$.

Euractiv (2014). 'EU Leaders to Meet for 'Informal' Talks, Two Days After Elections', 3 February 2014, available at http://www.euractiv.com/eu-elections-2014/van-rompuygathers-eu-leaders-in-news-533196 (accessed 1 February 2015).

European Parliament (2014). 'Press Release: The 2014 European elections: this time it's different', (2 November 2014, available at http://www.europarl.europa.eu/news/en/ news-room/content/20140210ipr35560/html (accessed 2 February 2014).

European People's Party (2002). A Constitution for a Strong Europe, Estoril, (accessed 18 October 2002).

European Voice (2014). 'Main Parties Bid to Firm up Grand Coalition', 3 July 2014, available at http://www.europeanvoice.com/article/main-parties-in-bid-to-firm-upgrand-coalition (accessed 1 February 2015).

Fabbrini, Sergio (2015a). Which European Union? Europe After the Euro Crisis. Cambridge: Cambridge University Press.

Fabbrini, Sergio (2015b). 'The European Union and the Puzzle of Parliamentary Government', Journal of European Integration, 37:5, 571-86.

Farrell, Henry, and Adrienne Héritier (2007). 'Codecision and Institutional Change', West European Politics, 30:2, 285-300.

Frankfurter Rundschau (2014). 'EU-Kommissionspräsident: Das Zögern der Kanzlerin', 1 June 2014, available at http://www.fr-online.de/europawahl/eukommissionspraesident-das-zoegern-der-kanzlerin,27125132,27315524.html (accessed 1 February 2015).

Hix, Simon, Amie Kreppel, and Abdul Noury (2003). 'The Party System in the European Parliament: Collusive or Competitive?', Journal of Common Market Studies, 41:2, 309-31.

Hobolt, Sara (2014). 'A Vote for the President? The Role of Spitzenkandidaten in the 2014 European Parliament Elections', Journal of European Public Policy, 21:10, 1528-40.

Höpner, Martin (2014). 'Spitzenkandidaten für die EU-Kommissionspräsidentschaft: Quantensprung der Demokratie?', Gesellschaftsforschung, 14:1, 2-5.

Juncker, J.-C. (2014). A New Start for Europe: My Agenda for Jobs, Growth Fairness and Democratic Change. Brussels: European Commission.

Marks, Gary, and Liesbet Hooghe (2009). 'A Postfunctionalist Theory of European Integration: From Permissive Consensus to Constraining Dissensus', British Journal of Political Science, 39:1, 1-23. 
NDR online (2014). 'Christdemokraten behandeln Juncker wie Aussätzigen', 28 May 2014, available at http://www.ndr.de/info/sendungen/interviews/Christdemokratenbehandeln-Juncker-wie-Aussaetzigen,lambsdorff132.html (accessed 1 February 2015).

Politico (2015), 'The Most Exclusive Dining Club in Brussels', 18 June 2015, available at http://www.politico.eu/article/g5-brussels-most-exclusive-dining-club/ (accessed 13 March 2015).

Schimmelfennig, Frank (2015). 'What's the News in 'New Intergovernmentalism'? A Critique of Bickerton, Hodson and Puetter', Journal of Common Market Studies, 53:4, 723-30.

Schmitt, Hermann, Sara Hobolt, and Sebastian Adrian Popa (2015). 'Does Personalization Increase Turnout? Spitzenkandidaten in the 2014 European Parliament Elections', European Union Politics, 16:3, 347-368.

Shackleton, Michael (2015). 'Whither the Parliament and the Commission? Reflections on the First Year of the Juncker Commission', in Gerrit Voerman and Jan van der Harst (eds.), De Commissie Juncker: Laatste Kans voor Europa?. Den Haag: Montesquieu Instituut, 81-94.

Skocpol, Theda, and Paul Pierson (2002). 'Historical Institutionalism in Contemporary Political Science', in I. Katznelson and H.V. Milner (eds.), Political Science: State of the Discipline. New York, NY: W.W. Norton, 693-721.

Spiegel Online (2014a). 'Künftiger Kommissionspräsident: EU-Parlament stellt sich hinter Juncker', 27 May 2014, available at http://www.spiegel.de/politik/ausland/junckerals-eu-kommissionspraesident-mehrheitssuche-im-europaparlament-a-971969.html (accessed 1 February 2015).

Spiegel Online (2014b). 'Gezerre um EU-Spitzenjobs: SPD verzichtet auf Kommissarsposten in Brüssel', 20 June 2014, available at http://www.spiegel.de/ politik/deutschland/schulz-und-juncker-spd-ueberlasst-kommissarsposten-derunion-a-976317.html (accessed 1 February 2015).

Tagesschau (2014). 'EVP kürt ihren Kandidaten für Europa', 7 March 2014, available at https://www.tagesschau.de/ausland/evp104.html (accessed 1 November 2015).

Westlake, Martin (2016). 'Chronicle of an Election Foretold: The Longer-Term Trends leading to the Spitzenkandidaten Procedure and the Election of Jean-Claude Juncker as European Commission President', LSE Europe in Question Paper No.102/2016. 